\title{
Empirical Test on Impact of Monetary Policy and Fiscal Policy on Vietnam Stock Market
}

\author{
Tu Tran Thi Thanh ${ }^{1}$, Linh Pham Thuy ${ }^{1}$, Tiep Nguyen Anh ${ }^{1}$, Thuy Do Thi ${ }^{1} \&$ Thơ Thị Hoai Trương ${ }^{1}$ \\ ${ }^{1}$ Faculty of Finance and Banking, VNU University of Economics and Business, Vietnam \\ Correspondence: Assoc. Prof., PhD. Tu Tran Thi Thanh, Faculty of Finance and Banking, VNU University of \\ Economics and Business, Vietnam. Tel: 84-90-438-5858.
}

Received: February 17, 2017

Accepted: March 21, 2017

Online Published: April 8, 2017

doi:10.5430/ijfr.v8n2p135

URL: https://doi.org/10.5430/ijfr.v8n2p135

\begin{abstract}
This research evaluates impact of monetary policy tools and fiscal policies on Vietnam's stock market, as well as examines interaction between these two policies with the Vietnam stock price index. Utilizing Vector error correction model (VECM), with 9 variables and data monthly statistics from January 2002 to October 2015, this study confirms that there are links between monetary policy, fiscal policy with Vietnam's stock market. In addition, Vietnam's stock market is also affected by exogenous factors, namely the world oil prices and the S\&P500 index, especially when Vietnam's economy is opening up and integrated with the global economy.
\end{abstract}

Keywords: monetary policy, fiscal policy, stock market

\section{Introduction}

In Vietnam, the stock market plays an important role in mobilizing and allocating a large amount of capital to achieve the goal of industrialization and modernization: a sustainable development economy, an efficiency economy restructure, a competitiveness improvement. Vietnam stock market officially operationed in the year of 2000 with only two listed companies with market capitalization reached 986 billion ( $0.28 \%$ of GDP at this time). After 10 years of performace, the two stock exchanges in Hanoi and Ho Chi Minh City has more than 678 listed companies and more than 200 UPCoM registered company who are upcoming listed. For over 15 years, the stock market has mobilized a huge amount of capital that up to 2 million billion VND so far, market capitalization ups to 34\% of GDP, a 114 times increased in comparison to the beginning. The market capitalization of shares and shares value traded has reached $1,300,000$ billion (a 1,300 times increased) and more than 2,000 billion/session (a 1,400 times increased) respectively. The stock market is now functioning as a channel for capital mobilization of the economy, acheived an important part of the financial markets. However, the stock market is very sensitive to macroeconomic changes as well as to the behavior and psychology of investors, so just a small mistake will create disruption on the financial markets, affecting to the entire economy. This explains why the development and stability of securities markets is the most concerns in economic development of each nation. For sustainable economic growth purpose, the government must issue the macroeconomic policies and the two most deciding tools in the economy management are the monetary policy and fiscal policy. Through fiscal policy, the government uses taxation and public spending tools to regulate the overall spending of the economy. And through the monetary policy, the State Bank can adjust the money supply level, interest rate and the money multiplier, which directly impact on monetary circulation, by using many different monetary tools. Each change in monetary policy or fiscal policy would have created an either direct or indirect impact on the stock market. Therefore, the lack of combination between monetary policy and fiscal policy exposes significant challenges for fiscal balance and monetary stability of the economy.

From seeing the strengths and weaknesses points of each policy may impact positively or negatively on the stock market then the investors and policy agencies need to consider about the relationship between macroeconomic policies with the stock market. Therefore, this study mainly focuses on assessment the impact of monetary policy and fiscal policy tools on Vietnam stock market to forecast the stock market reaction as well as the interaction of two these policies and making recommendationsfor investors and policy makers based on the results. 


\section{Literature Review}

Financial market in general and stock market in particular plays an important role in developing economics in each country. Especially, "stock markets are sensitive to information", (Liya Wang, 2010). According to Galbraith (1955), (quoted in Singh Shivangi \& Jotwani Naresh (2012)) "the stockmarket is but a mirror, which provides an image of the underlying or fundamental economic situation". In reality, researches about the relationship between macroeconomics policies and stock market draws policy makers and scholars' much attention.

Besides evaluating the effect of monetary policy and fiscal policy on stock market individually, many researchers also have empirical researches to determine how the combination of these policies has effects on stock market. According to this approach, researchers find out not only the changes in stock market connected with the changes in both macroeconomics policies but also the interaction between monetary policy and fiscal policy in explaining the activities of stock market.

Franco Fiordelisi and Giuseppe Galloppoc (2015) measured the stock market's response as the changes in monetary policy and fiscal policy. This research was based on stock index of eleven countries, which are: U.S, Britain, Sweden, Switzerland, Spain, Holland, Japan, Italy, Germany, China and Belgium, during the period from 2007 to 2013. In addition to give recommendations for policy makers, it was also a reference for investors and risk managers to make decisions appropriately. For Pakistan market, Waseem Ahmad Khan (2014) had found the same results that relating to the impact of macroeconomics variables on stock market. However, there are some differences between the researches. Yu Hsing (2013) revealed that the monetary policy affected stock index but it was not correct for fiscal policy in Poland market. Besides, the author also determined the stock index of the U.S and Germany had considerable effect on stock market performance in Poland.

Studies about Southeast Asian countries provided new approaches to analyze the response of stock market and focused more onthe practicability of the researches. Rossanto Dwi Handoyo et al. (2013) evaluated stock prices response in general and agricultural, mining, manufacture, and financial sector indexes in particular to macroeconomics policies shock. The more specific the researches are, the more investors understand about stock market and how each sector in economy changes. On the whole, stock market had positive response to monetary policy shock and negative policy response to fiscal policy. Another research about Malaysia, the authors found the relationship between macroeconomics policies and stock market performance by using VECM model (vector error correction model). Besides, they also confirmed the research's application in reality. Thus, both monetary policy and fiscal policy play a critical role in Malaysia stock market. Nevertheless, monetary policy affected stock index faster than fiscal policy did. Specifically, this study not only helped policy makers and authorities comprehend stock market's behavior but also knew the benefits of using information to achieve monetary goals. Moreover, "this finding would give a signal to the investors to strategize their investment decisions in the short and long run" (Hussain Ali Bekhet et al. (2012)). It is significant for researchers to find more factors effecting on stock market. For the case of Singapore, Ghulam Ali et al. (2014) revealed the significance of researching this subject. The reason was that policy makers and investors would have a glance at the financial market in the future as the changes in monetary policy and fiscal policy were implemented. In summary, the researches all applied econometrics methods to measure the stock market responses when Government made the adjustments in macroeconomics policy. In addition, the studies in the past also found the relationship between monetary policy, fiscal policy and stock market performance. It was generally valuable for policy makers to develop stock market and for investors to make the investment decisions.

Duong Ngoc Mai Phuong et al (2015) gave more details about the impact of monetary policy on Vietnam stock market. Through SVAR model, the study revealed that there was a close relationship between stock index and monetary policy. In addition, stock market also played a vital role in the transmission mechanism of monetary policy for the achivevement of quantity growth, price targets and the promulgation of monetary policy. Meanwhile, Nguyen Phuc Canh (2014) researched the asset price channel to assess the impact of monetary on stock market. Although the author applied SVAR model, he used the original data series which were non-stationary, which could cause an inaccurate model, so it may not estimate the relationship between the variables in the long run because of the cointegration. Besides, the ignoring of the Granger causality test in the model would lead to the disorder of the variables of the model, which may reduce the accuracy and reliability of the estimated model.

In conclusion, the research about the relationship between the macroeconomics factors and stock market performance is a subject which got much attention by the researchers. However, there were just studies about the impact of monetary policy in Vietnam, not the ones related to the fiscal policy. In addition, those authors just focused on evaluating the effect of responds and did not forecast the changes in the future that were valuable to investors. Therefore, the authors want to test the effects of monetary policy and fiscal policy as well as the interaction between these policies on 
influencing stock market activities in Vietnam. Also, we will give the forecast for the market based on the econometrics analysis.

\section{The Changes in Monetary Policy - Fiscal Policy and the Vietnam's Stock Market}

* Monetary policy and fiscal policy

During the period 2000-2015, Vietnam economy witnessed many strong movements, especially, the impact of the crisis in the region and the world. This required the Government to adopt flexible, effective macroeconomic policies and in a timely manner to help the national economy overcome difficulties and achieve the targets of growth in each period.

In the period of 2000-2006: The percentage of Expenditure on GDP ratio and budget deficit soared since the government implemented expansion policies to achieve the objective of economic recovery and stimulate growth after the Asian financial crisis.

Period 2007-2008: Vietnam economy suffered from the effects of the global financial crisis. As the result, the economic growth rate decreased from $8.48 \%$ (2007) to $6.31 \%$ (2008). Besides, the prioritized target in this period was to control inflation - a consequence of the increased in aggregate demand in the previous period. In addition to resolve the difficulties in this period, the Government implimented tight monetary policy and fiscal policy, reduced the budget deficit from $6.8 \%$ (2007) to $1.4 \%$ (2008) and flexibly used the tools of monetary policy such as: (i) the required reserved ratio increased; (ii) the provision of central bank bills not be used to refinance at the central bank; (iii) The base rate increased; (iv) controlling the credit quota and requiring tightly controlling the high-risk borrowing fields.

During the period 2009-2011: After the global economic crisis, the Government implemented the economic stimulus package. The first $\$ 1$ billion worth package was to support the interest rates cost for small and medium enterprises and the second package worth approximate $\$ 8$ billion to support medium and long term interest rates cost to encourage investment and production development. However, the government tightened fiscal policy to curb inflation in the coming years through measures such as: (i) increasing base interest rate, discount rate, and refinancing rate; established ceiling deposit interest rate; (ii) increasing reserved requirement; (iii) rising exchange rate; (iv) limiting credit growth money supply and (v) cutting investment, saving $10 \%$ of spending.

With the recovery of domestic economy's growth ratefrom 2012 until the end of 2015, the objective of macroeconomic policy also has changed which are now focusing on macroeconomic stability and supporting enterprises instead of curbing high inflation which is the main target in the period 2010-2011. Specifically, for fiscal policy, the Government is operating towards strictly manage revenue as well as savings and reducing the nation budget deficit. Monetary policy focused on exchange rate stability, inflation curb go along with the credit policy toward supporting the production, removing difficulties for the business sector.

\section{* The development of Vietnam's stock market}

The launch of Vietnam's stock market was marked by the event that Securities Trading Center City. Ho Chi Minh went into operation on 20 July, 2000. The first session took place later on July $28^{\text {th }}$ with only 2 kinds of share were listed with the amount of capital mobilized 270 billion dong and a few of government bonds. For the early stages of formation and development (2000-2005), the stock market was only with a small amount of listed companies, sparse commodities and transactions. However, in this period, foreign investors appeared - with the highest percentage of holding shares was $30 \%$.

Then, Vietnam stock market went into a breakout period 2006-2007, trading activities took place more bustle on both stock exchanges in Ho Chi Minh, Hanoi and OTC markets. The market size increased rapidly and reached $22.7 \%$ of GDP in 2006 and $43 \%$ in 2007. The number of listed companies increased with the amount of capital mobilized nearly 40,000 billion dong in 2007. In 2009, the stock market changes returned positively, that presented though both VNIndex and HNX-Index raised above 50\%, the number of listed companies in both two trading centers was 541 at the end of the year, the total market capitalization was 620.551 trillion dong and equivalent to $38 \%$ of GDP.

The period 2010-2012 witnessed fluctuations in the stock price Vietnam index due to the situation in the country and the international, such as the European debt crisis or high inflation, unstable exchange rates... However, the stock market began recovery powerfullyin 2013 when inflation rate was controlled, interest rates reducted, foreign reserves increased and the deployment of securities tax-deductible transfer solutions. VNIndex rose nearly $23 \%$ and HNX-Index increased above 13\% compared to the end of 2012. So, 2013 can be considered as an establishment for the stabilization of market in 2014. However, many market sessions still declined due to the impact of event in the South China Sea and world oil prices. 
In 2015, the macroeconomic condition was more positive; however, the stock market experienced a fluctuation, the growth of the Index was 5\% due to the influence of external factors, the strongest ones were the exchange rate fluctuations and the falling in oil prices. Besides those changes, the undeniable growth of Vietnam's stock market after more than 15 years of operation made remarkable progress with market capitalization of over 1.3 million billion dong, equivalent to $34 \%$ of GDP with average trading per session reached 4.964 billion with 682 stocks listed on the two trading centers.

In the strategy for Development Vietnam stock market in 2011-2020, the Prime Minister signed Decision No. 252/QD-TTg oriented VN stock market aim to: increase the size, depth and liquidity Terms of the stock market; strive for bringing the total market capitalization reached 70\% GDP in 2020, this shows that the stock market becoming major channel for capital mobilization is really one of the great objectives of the Government on the way to completing the objectives of the industrialization - modernization country.

\section{Research Methodology}

This research's purpose is to evaluate the impact of monetary policy and fiscal policy on Vietnam stock market during the period 2000-2015. Besides, the authors reveal how the exogenous variables affect stock index.

Table 1. The variables in the research

\begin{tabular}{llll}
\hline & Variables & Abbreviate & \multicolumn{1}{c}{ Sources } \\
\hline Exogenous variables & Oil Price & Oil & Energy InformationAdministration \\
& US Stock Index & SP500 & Chicago Board Options Exchange \\
Monetary policy & Money Supply(M2) & M2 & $\begin{array}{l}\text { International Monetary Fund, } \\
\text { State Bank of Vietnam }\end{array}$ \\
& Vietnam Basic Interest Rate & IR & International Monetary Fund \\
Fiscal policy & Budget Expense on GDP & Expense & General Statistics Office of Vietnam \\
& Budget Revenue on GDP & Revenue & General Statistics Office of Vietnam \\
The interaction & Price Consumer Index & CPI & International Monetary Fund \\
between these policies & Budget Deficit & Deficit & General Statistics Office of Vietnam \\
Dependent variable & Vietnam Stock Index & VNIndex & State Security Commission of Vietnam, \\
& & & VNDIRECTSecurities Corporation
\end{tabular}

Source: Synthesized by the authors

Table 2. Describing the variables

\begin{tabular}{ll}
\hline \multicolumn{1}{c}{ Variables } & \multicolumn{1}{c}{ Describing the variables } \\
\hline Oil Price & Converted at the exchange rate of VND/USD in 2010 \\
US Stock Index & The monthly average of S\&P500 at the end of market-day \\
Money Supply & Monthly M2 in price of 2010 \\
Vietnam Basic Interest Rate & Monthly Vietnam basic interest rate \\
Budget Expense on GDP & The percentage of budget expense on GDP \\
Budget Revenue on GDP & The percentage of budget expense on GDP \\
Price Consumer Index & Monthly consumer price index \\
Budget Deficit & Monthly deficit in price of 2010 \\
Vietnam Stock Index & The monthly average of VNIndex at the end of market-day \\
\hline
\end{tabular}

Source: Synthesized by the authors 
Vector autoregression model (VAR) is a model used to determine the linear impact between time series variables. VAR model is built from simple autoregression models. Each variable has an equation which explains the development of this variable based on its lag and the others' lag. However, VAR model often reflects the short-run relationship between variables. In addition, the variables must satisfy two conditions which are stationary and non-cointegration. Unless these conditions are satisfied, using VAR can cause the spurious regression problem. Granger and Newbold (1973) were the first people to lay the foundation for this problem. They hypothesized that there were two times series variables which totally had no relationship and were non-stationary. Then, they made a regression model between these variables. As a result, there was a clear relationship between them and statistics were meaningful. In fact, the result was not accurate.

Vector error correction model (VECM) - an extended model of VAR - was developed to solve this problem. In VECM model, time series also were stationary. Besides, we need to add a vector error correction with the length which equals to cointegration relationship between series in the model. In addition, VECM can estimate the long-run relationship between time series. Therefore, VECM model is widely used to evaluate the impact of macroeconomic variables which are time series and cointegration in the long-run. Guglielmo Maria Caporal et al (2010) tested the relationship between monetary policy and exchange rate during the Asian financial crisis by using VECM model. Muhamad Abduh (2009) revealed the short-term and long-term relationship between US monetary policy and Indonesia stock market through VECM model. Then, the author gave recommendations to improve the effect of monetary policy and avoid external impacts.

Fahad Alturki and Svetlana Vtyurina (2010) used VECM model to analyze the impact of inflation on monetary policy in Tajikistan. Researches with VECM models indicated that the effect of monetary policy on the stock market through each stage varied from country to country (Aziza O.F. Francis, 2010). Based on theoretical and empirical findings of the previous studies, we decided to choose VECM model to evaluate the stock market's responses to the changes in monetary policy and fiscal policy.

To conveniently construct the equations, we use an alphabet words to mark the variables. V, O, S, M, I, R, E, C, D are stand for VNIndex, Oil Price, S\&P500, Money Supply, Interest Rate, Budget Revenue, Budget Expense, Consumer Price Index and Budget Deficit respectively.

In this model, VNIndex is a dependent variable and the others are independent ones. We have:

$$
V_{t}=f\left(O_{t}, S_{t}, M_{t}, I_{t}, R_{t}, E_{t}, C_{t}, D_{t}\right)
$$

VECM model is estimated through three basic steps. Besides, the hypothesis is the time series variables are stationary.

Step 1: Estimating the VAR model by constructing the vector regression equation for each variable.

Step 2: Testing the variables' cointegration by using the Johansen methodology.

Step 3: If there is at least a cointegration. VECM model will be estimated based on VAR model which is built earlier.

\section{Test Results}

Table 3. Unit root test

\begin{tabular}{|c|c|c|c|c|c|}
\hline \multirow[t]{2}{*}{ Variables } & \multirow[t]{2}{*}{ Form } & \multirow{2}{*}{ t-test (significance at the $5 \%$ level) } & \multicolumn{2}{|c|}{ Stationary (ADF) } & \multirow{2}{*}{ Lag length } \\
\hline & & & Origin & Differenced 1 times & \\
\hline Oil & $\log$ & -5.711 & & $\mathrm{x}$ & 5 \\
\hline S\&P500 & $\log$ & -5.625 & & $\mathrm{x}$ & 5 \\
\hline M2 & $\log$ & -6.213 & & $\mathrm{x}$ & 3 \\
\hline IR & $\%$ & -10.617 & & $\mathrm{x}$ & 0 \\
\hline Revenue & $\log$ & -7.091 & & $\mathrm{x}$ & 4 \\
\hline Expense & $\log$ & -7.059 & & $\mathrm{x}$ & 6 \\
\hline Vnindex & $\log$ & -3.403 & & $\mathrm{x}$ & 11 \\
\hline CPI & $\log$ & -3.170 & & $\mathrm{x}$ & 13 \\
\hline Deficit & Gốc & -6.288 & & $\mathrm{x}$ & 12 \\
\hline
\end{tabular}

Source: Caculated by the authors 
Table 4. Lag Length Criteria

\begin{tabular}{ccccccc}
\hline \hline Lag & LogL & LR & FPE & AIC & SC & HQ \\
\hline 1 & 374.1502 & NA & $2.66 \mathrm{e}-12$ & -3.950958 & -2.705100 & -3.444971 \\
2 & 685.9606 & 560.0670 & $1.14 \mathrm{e}-13$ & -7.107778 & $-4.616062^{*}$ & -6.095805 \\
3 & 836.9412 & 255.8016 & $3.81 \mathrm{e}-14$ & -8.215811 & -4.478237 & -6.697851 \\
4 & 994.5298 & 250.9372 & $1.19 \mathrm{e}-14$ & -9.408023 & -4.424590 & $-7.384076^{*}$ \\
5 & 1068.570 & 110.3526 & $1.09 \mathrm{e}-14$ & -9.535921 & -3.306630 & -7.005987 \\
6 & 1174.779 & 147.4755 & $6.85 \mathrm{e}-15$ & -10.07362 & -2.598472 & -7.037701 \\
7 & 1296.215 & $156.2419^{*}$ & $3.64 \mathrm{e}-15^{*}$ & $\mathbf{- 1 0 . 8 0 5 2 8 *}$ & -2.084276 & -7.263377 \\
$*$ *: Indicates lag order selected by the criterion. & & & & \\
\hline \hline
\end{tabular}

Source: Caculated by the authors

The authors define the relationship between the variables following Johansen method with optimal lag is 7 by using two standards AIC and SC. Both standards give results which have cointegration between variables, which is the base for using VECM model.

According to the above examination, these standards offer two different type of model. To decide which standards to use the model, the researchers estimated VECM model in both standards and selected a model with a higher level of significance.

The variables used in the model: loil, lsp500, lrevenue, lcpi, deficit, lexp, lvninex, ir, $\operatorname{lm} 2$. The ordinal of the variables is sorted according to the principle of from least affected variable to most affected variable on the basis of Granger causality test.

Results which estimates VECM model in two standard models show that the standard AIC has higher levels of significance. Therefore, the authors use the standard model VECM according to AIC.

Table 5. Coefficient of determination

\begin{tabular}{ccc}
\hline \hline Standard & AIC & SC \\
\hline \hline $\mathrm{R}^{2}$ & 0.706185 & 0.672895 \\
$\overline{\mathrm{R}}^{2}$ & 0.470449 & 0.442843 \\
\hline \hline
\end{tabular}

Source: Caculated by the authors

Table 6. Residual groupunit root test

\begin{tabular}{lccc}
\hline \hline Method & Statistic & Prob. & Obs \\
\hline Null: Unit root (assumes common unit root process) & & & \\
\hline Levin, Lin \& Chu t* & -40.5388 & 0.0000 & 1393 \\
& & & \\
\hline Null: Unit root (assumes individual unit root process) & & & 1393 \\
\hline Im, Pesaran and Shin W-stat & -35.7928 & 0.0000 & 1393 \\
ADF - Fisher Chi-square & 732.526 & 0.0000 & 1395 \\
PP - Fisher Chi-square & 781.095 & 0.0000 & \\
\hline \hline
\end{tabular}

Source: Caculated by the authors 
The purpose of testing the stationary residuals is to check the suitability of the model. According the result, the residuals of the VECM model is stationary at the 5\% level with p-value equals to 0 ; so that, the model was fit for time-series data.

To make models be highly reliable, the residual of the model must have no Heteroskedasicity. Test results shows that the residuals of White have no Heteroskedasicity phenomenon at the 5\% significance level.

Table 7. Residual Heteroskedasticity test

VEC Residual Heteroskedasticity

Included observations: 156

\begin{tabular}{cccc}
\hline \hline Joint test: & & & \\
\hline \hline Chi-sq & df & Prob. \\
6274.696 & 6210 & 0.2794 \\
\hline \hline
\end{tabular}

Source: Caculated by the authors

Table 8. Autocorrelation LM Test

VEC Residual Serial Correlation LM Tests

Null Hypothesis: no serial correlation at lag order $\mathrm{h}$

\begin{tabular}{ccc}
\hline \hline Lags & LM-Stat & \\
\hline 1 & 108.4081 & Prob. \\
2 & 120.4468 & 0.0227 \\
3 & 78.15323 & 0.0294 \\
4 & 104.9264 & 0.5690 \\
5 & 99.23230 & 0.0382 \\
6 & 72.36103 & 0.0825 \\
7 & 73.51318 & 0.7427 \\
8 & 90.12064 & 0.7104 \\
\hline \hline
\end{tabular}

Source: Caculated by the authors

Testing autocorrelation among the residuals of the model shows that the residuals of the model with different latencies have no autocorrelation at the $1 \%$ significance level. Thus, VECM model is satisfied.

Inverse Roots of AR Characteristic Polynomial

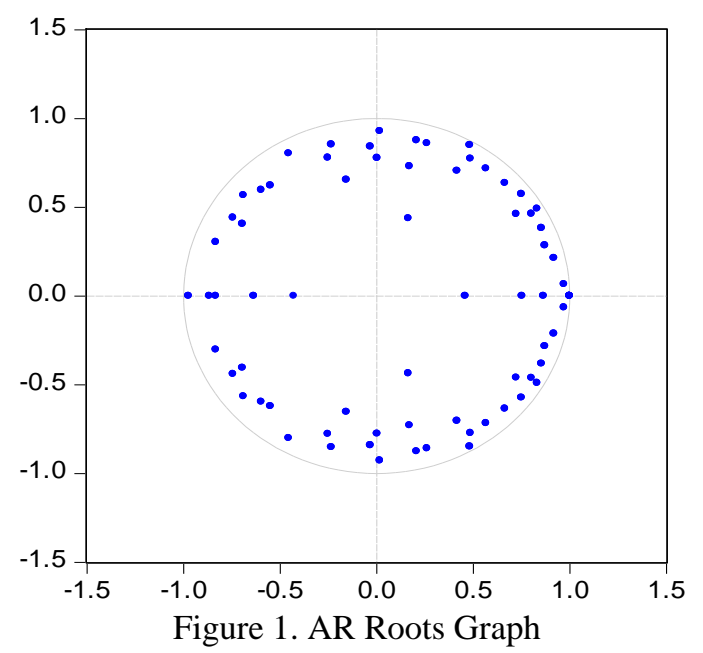

Source: Caculated by eviews 9.0 
A VAR model is stable when its unit roots are less than 1 and inside of the unit circle. The test results show that the smaller polynomials roots are smaller than 1 and within the unit circle (these are 4 roots larger than 1is VECM model imposed by VECM model which equal to thevariables in the model minus the number of cointegration), VECM model is stable and acceptable.

Then the authors made a forecast about VNIndex for the year of 2016 by using the data collected.

Table 9. Forcasting VNIndex for the year of 2016

\begin{tabular}{cccc}
\hline \multirow{2}{*}{ Time } & \multirow{2}{*}{ VNIndex } & \multicolumn{2}{c}{ Significance at the 5\% level } \\
\cline { 3 - 4 } & & Lower & Upper \\
\hline $12 / 2015$ & 566.69 & 547.33 & 586.05 \\
$01 / 2016$ & 567.02 & 540.81 & 593.23 \\
$02 / 2016$ & 577.53 & 545.67 & 609.38 \\
$03 / 2016$ & 586.26 & 549.67 & 622.85 \\
$04 / 2016$ & 588.99 & 547.96 & 630.02 \\
$05 / 2016$ & 585.33 & 540.63 & 630.02 \\
$06 / 2016$ & 579.26 & 531.19 & 627.33 \\
$07 / 2016$ & 578.82 & 527.61 & 630.02 \\
$08 / 2016$ & 577.83 & 528.32 & 632.72 \\
$09 / 2016$ & 575.54 & 519.26 & 631.82 \\
$10 / 2016$ & 574.86 & 516.99 & 632.72 \\
$11 / 2016$ & 576.42 & 517.43 & 635.41 \\
$12 / 2016$ & 577.96 & 524.11 & 631.82 \\
\hline
\end{tabular}

Source: Caculated by the authors

\section{Discussions and Recommendations}

Results of VEC model shows a close correlationbetween monetary policy and fiscal policy with Vietnam's stock market. Each policy has different impacts on the stock market depends on their targets. The study also points out the interaction effects between monetary policy and fiscal policy. In addition, the authors indicat that Vietnam's stock market also affected by external economic factors which is the S\&P500index and the world oil prices.

Firstly, monetary policy and stock market have a close relationship with each other. In short-run, the expansionary monetary policy which helps increasing the money supply has a positive impact on the stock market while tightening monetary policy has the opposite effect. But in the long-run, the stock index responses to monetary expansionin a negative way due to the increasing in the money supply will cause a rise in future inflation, then cause negative impact on the economy and the stock market. Similarly, the last studies revealed that there was a positive relationship between money supply and stock index. However, State Bank can not expand money supply forever because it will cause inflation in the economy. Therefore, monetary policy needs to be used flexibly and efficiently. Besides, interest rates have a positive impact on stock index in short term but negatively in the long term. Duong Ngoc Mai Phuong et al. (2015) found that the increase in interest rate would make stock market decline. Besides, Nguyen Phuc Canh (2014) showed that interest rate affected negligibly on VNIndex. The difference in the results of the researchers could be explained by the authors' choice. Each author chose the different types of interest rate. For this study, we chose "Basic interest rate" whereas Duong Ngoc Mai Phuong et al.'s choosed (2015) was "Discount rate". In addition, Nguyen Phuc Canh (2014) used three types of interest rate, which were "Refinance rate, Discount rate and Policy Rate".

The results of the study show that the stock index responses to both money supply M2 and interest rate increase positively in short-term and negatively in long-term. In present, when inflation rate below $1 \%$, the central bank should increase the level of money supply M2 and alleviate the interest rate for controlling inflation to stabilize the macroeconomic, therefore, make an effective environment for developing the stock market. But it also opens up challenges for the central bank to flexibly use policy tools, especially open market and interest rate tools, based on the response of stock index to macroeconomic factors. Depend on Granger causality test, causal links between money supply and the stock index, interest rates and the stock index have been confirmed. In 2016, though the world economy 
is forecasted to be growth, investors should focus economic factors which are highly affected by changing in monetary policy.

Secondly, a connection between fiscal policy and the stock market is also founded. An increase in fiscal spending, reflecting the expansionary fiscal policy, has a negative impact on the stock market in both the short-term and the long-term. This is the consequence of budget deficits that make the government borrow money which will raise a concern about inflation increased in the future. And the allocation of nation budget in Vietnam is mainly concentrated in non-investment expenditure which has a negative impact on the economy.

In addition, the stock market is negatively affected by tight fiscal policy. The increased in nation budget may reflecting the rising in tax causing both the consumers and enterprises have to pay an extra cost for consuming and producing. Therefore, the government must use its budget in an effective way, avoiding the budget deficit, controlling and reasonable allocating funds. Especially when Vietnam's public debt is now dramatically rising, accounted for nearly 61.3 percent of GDP in 2015 (Ministry of Finance).

Thirdly, the research points out that both monetary policy and fiscal policy not only affect the stock market on their own but also impact the stock market through their interaction, which can be represented by 2 variables: Consumer Price Index (CPI) and Budget Deficit. An increased in CPI is the consequence of risen inflation rate and this causes adverse effects to the stock market. Both researches of Duong Ngọc Mai Phuong et al. (2015) and Nguyen Phuc Canh (2014) showed the similar consequence about the relationship between inflation and stock index. Because investors now have less attraction for stock investing, and priority for buying gold or making a saving deposit. The budget deficit is showing that the government's spending exceeded its income, so the government must borrow money to cover their spending through issuing bonds. In the long-term, the inflation rate raises dramatically and negatively affects the economy as well as the stock market. Therefore, to fulfil the major target of both monetary policies and fiscal policy, with a stabilized inflation rate, the interaction between these two policies must be taken seriously. On the one hand, money supply and interest rate need to be adjusted reasonably. Andthe budget spending must now be more saving and efficiency, avoiding budget deficit that cause many negative effects to the economy. So that, stabilizing inflation and economic growth targets can be fulfilled.

Fourthly, the stock market reacts not only with the endogenous variables, but also with the exogenous variables, namely the US stock index (S\&P500) and the oil price. The increase in US stock index shows a strong growth in the world economy, which positively influences the stock market but has a slight negative effect on the stock market in the long run. Meanwhile, the oil price has different effects on the stock market over each period, but mostly negative effects. Nguyen Phuc Canh (2014) also measured the impact of oil price on stock market. The result was VNIndex flucated at different times. Therefore, in addition to an analysis of domestic policies, investors need to pay attention to external factors, which have a strong effect on the developing economies like Vietnam. Moreover, Vietnam stock market needs to be developed, in line with international practice. Thereby reducing the effect of exogenous factors on the stock market and minimizing risk for investors.

Besides, the authors also use VECM model to forecast the Vietnam stock index (VNIndex) from December, 2015 to December, 2016. The anticipated results are in line with actual results by the end of April, 2016. Based on the anticipated results, we can see that the stock index will decrease from May to October, then increase in November and December, with the maximum at 631.82 points. This prediction is consistent with the forecast of Vietnam economy in 2016, which expected to continue to grow rapidly.

\section{Limitations}

This study has some limitations in data analysis because of limited access to data. So in our next researches, we will try to complete the dataset and implement the stock indexes classified by sectors (minning, finance, agriculture...). The evaluation of these indexes will bring more practical value, especially for investors. Because VNIndex represents for the stock market in general, meanwhile, manufacture - business characteristics have some certain differences, so changes in macroeconomic factors will have different effects on stock sector index. Therefore, the analysis of both VNIndex and sector index will help decision makers and investors get not only the panoramic view, but also the sector - specific activities, which let decision makers give appropriate policies and investors make accurate decisions.

\section{References}

Abduh, M. (2009). The Linkage of US Monetary Policy and Stock Markets toward Indonesia Stock Markets.

Ahmad, W. K. (2014). Impact of Macroeconomics variable on the Stock Market index; A Study from Pakistan. International Journal of Accounting and Financial Reporting, 4(2), 258-272. 
Asian Development Bank. Retrieved from www.adb.org/

Aziza, F.O.F. (2010). The Effects of Monetary Policy on Stock Market Performance: A Cross-Country Analysis.

Chicago Board Options Exchange. Retrieved from http://www.cboe.com/

Coordination of Fiscal Policy and Monetary Policy in Vietnam in the period 2011-2015 and solutions towards 2020. Journal of Finance.

Duong Ngoc Mai Phuong, Vu Thi Phuong Anh, Do Thi Truc Dao \& Nguyen Huu Tuan. (2015). The impact of monetary policy on the stock market: Evidence in Vietnam. Journal of Development \& Integration, 3(35), 37-45.

Energy Information Administration. Retrieved from https://www.eia.gov/

Fahad Alturki, \& Svetlana Vtyurina. (2010). Inflation in Tajikistan: Forecasting Analysis and Monetary Policy Challenges.

General Statistics Office of Vietnam. Retrieved from https://www.gso.gov.vn/

Ghulam Ali, Khalid Zaman, Sayed Mahdi Ziaei, \& Melati Ahmad Anuar., (2014). Stock Return Response to Monetary and Fiscal Policy Interaction in Singapore. Mediterranean Journal of Social Sciences, 5(27). https://doi.org/10.5901/mjss.2014.v5n27p1712

Grange, C. W. J., \& Newbold, P. (1973). Spurious regressions in Economies. Journal of Econometrics 2(1974), 111-120.

Guglielmo Maria Caporale, \& Alaa M. Soliman. (2010). Stock Prices and Monetary Policy: An Impulse Response Analysis.

Handoyo, R.D., Jusoh, M., \& Zaidi, M.A.S. (2015). Impact of Monetary Policy and Fiscal Policy on Indonesian Stock Market. Expert Journal of Economics, 3(2), 113-126. Retrieved from http://economics.expertjournals.com/23597704-312/

Hsing, Y. (2013). Effects of Fiscal Policy and Monetary Policy on the Stock Market in Poland. Economies, 19-25.

Hussain Ali Bekhet, \& Nor Salwati bt Othman. (2012). Examining the Role of Fiscal Policy in Malaysian Stock Market. International Business Research, 5(12). https://doi.org/10.5539/ibr.v5n12p59

International Monetary Fund. Retrieved from http://www.imf.org/

Ministry of Finance. Retrieved from http://www.mof.gov.vn/

Nguyen Anh Phong. (2016). The impact of fiscal policy on Vietnam's economy and recommendations. Journal of Finance, 2(2).

Nguyen Phuc Canh. (2014). Transmission of monetary policy through the financial asset price channels: experimental study in Vietnam. Journal of Development and Integration, 19(29).

Shivangi, S., \& Naresh, J. (2012). The Effect of Macroeconomic Variables on Stock Prices: A Conceptual Framework of the Arbitrage Pricing Theory. Journal ofManagement and Research, 5, 1-16.

State Bank of Vietnam. Retrieved from http://www.sbv.gov.vn/

State Security Commission of Vietnam. Retrieved from http://www.ssc.gov.vn/

To Kim Ngoc, \& Le Thi Tuan Nghia. (2012). Coordination of Fiscal Policy and Monetary Policy in Vietnam.

Tran Tho Dat, \& Dang Ngoc Duc. (2016). Monetary Policy in the period 2011-2015 and its impacts on the economy. Journal of Economics and Forecast, (3).

VNDIRECTSecurities Corporation. Retrieved from https://www.vndirect.com.vn/

Wang, L. (2010). The Effect of Government Policy on China's Stock Market. 